\author{
International Journal of Entrepreneurship and \\ Management Practices (IJEMP) \\ Journal Website: http://ijemp.com/ \\ eISSN: $2600-8750$
}

\title{
THE EFFECT OF BROADCAST SEARCH AND IDEATION COMMUNITY CONTEST ON FIRMS' INNOVATION: THE MEDIATING ROLE OF RELATIONSHIP QUALITY
}

\author{
Ripan Kumar Saha ${ }^{1 *}$, Tey Lian Seng ${ }^{2}$, Azni Zarina Taha ${ }^{3}$, Sharan Kaur Garib Singh ${ }^{4}$ \\ 1 Department of Business Policy \& Strategy, University of Malaya, Malaysia \\ Email: ripansa@gmail.com \\ 2 Department of Business Policy \& Strategy, University of Malaya, Malaysia \\ Email: teyls@um.edu.my \\ 3 Department of Business Policy \& Strategy, University of Malaya, Malaysia \\ Email: aznitaha@um.edu.my \\ 4 School of Business, Whitireia Community Polytechnic, Auckland, New Zealand \\ Email: Sharan.Kaur@whitireia.ac.nz \\ * Corresponding Author
}

\section{Article Info:}

\section{Article history:}

Received date:03.05.2020

Revised date: 13.06 .2020

Accepted date: 14.06 .2020

Published date: 15.06 .2020

\section{To cite this document:}

Saha, R. K., Tey, L. S., Taha, A. Z., \& Singh, S. K. G. (2020). The Effect of Broadcast Search and Ideation Community Contest on Firms' Innovation: The Mediating Role of Relationship Quality. International Journal of Entrepreneurship and Management Practices, 3 (10), 52-73.

DOI: $10.35631 /$ IJEMP.310005.

\begin{abstract}
:
In the modern business world, firms gain enormous success in innovation by using social media. This approach ostensibly reduces firms' cost by decreasing reliance on internal research and development. Organizations often use knowledge from other organizations and customers by using social media for innovation. Therefore, the purpose of this research is to explore the impacts of broadcast search and ideation community contest on innovation. Additionally, this study aims to narrow the gap by investigating the mediating role of relationship quality between the two dimensions of social media activities and innovation, respectively. Employing a sample of 393 manufacturing firms in Malaysia, our results confirm that the broadcast search and ideation community contest dimensions of social media activities are positively associated with relationship quality, but ideation community contest also impact on innovation. Further, the results provide evidence that relationship quality plays a mediating role between ideation community contest and innovation. The central arguments regarding social media activities and their relationship to innovation transcend national boundaries, and many of the policy recommendations are important for Malaysian manufacturing firms.
\end{abstract}

Keywords:

Social Media, Broadcast Search, Ideation Community Contest, Innovation, Relationship Quality, Malaysia 


\section{Introduction}

The rapid growth of information technology and the Web 2.0 based communication system such as social media have revolutionized opportunities for organizations to interact with customers for ideas which can be used to enhance their innovative and creative capabilities. These may be utilized to develop innovative products or for new innovations (PalaciosMarqués et al., 2015; Scuotto et al., 2017). It is fundamental for organizations to innovate their products and services in view of reacting to the changing customer demands, and ways of life in order to capitalize prospects offered by the changing technology, marketplaces, and structures. Zahra and Covin (1994, p. 183) recommend that "Innovation is broadly considered as the backbone of corporate survival and development". Innovation can be performed in association with products, services, operations, techniques, and individuals (Baregheh et al., 2009).

In earlier years firms relied on innovation process to be competitive and to bring new product to the market (Chesbrough, 2006), without or very limited interaction with the external environment and consumers which is called the traditional process (Lichtenthaler \& Ernst, 2008). In this traditional innovation model, the assumption was that the innovation processes need to be controlled by the firm and heavily depend on its internal R\&D (Ramaswamy, 2008). However, in the modern innovation model organization rarely innovate alone. They gather idea and knowledge for innovation process from external source to sustain in competitive advantage in the current world (Ritala \& Hurmelinna-Laukkanen, 2013), and that innovation is a result of interactive relationships among producers, users, and many other different institutions (Laursen \& Salter, 2006). Due to rapid technological changes taking place, high R\&D cost, and other factors of globalization, sticking to this traditional product development process can lead to loss of competitive advantage for a firm. On the other hand, embracing user interaction in the innovation model can result in important strategic innovations providing firms with competitive advantage (Prahalad \& Ramaswamy, 2004; Orcik et al., 2013). Therefore, many firms in various industries are trying to build up a relationship with their customers and engaging them in product innovation processes to understand their needs (von Hippel, 2001). The most popular forms of customer engagement for product innovation is social media (Kaplan \& Haenlein, 2010). Social media activities give entirely novel and useful customer interaction platforms where customers can share their needs and ideas in the product innovation process (Jussila et al., 2013). The challenge for an organization is to select appropriate and affordable social media platform (Palacios-Marqués et al., 2015). Which have not yet been tremendously explored as a result of the novelty of social media ideas and approaches, and the conceivable outcomes of social media are not completely comprehended with regards to innovation. Prior researchers have found that broadcast search and ideation community contest are significant platforms for interacting with external communities like customer, supplier, and business for innovation process (von Hipple, 2001; Laroche et al., 2012). However, adopting the social media platforms for innovation does not seem to be very easy. So, social media activities may provide customers with a platform that can effectively captivate the interests of users, the terrible word-of-mouth instigation can also put more risks to the reputation of the organization (Tripp \& Gregoire, 2011). This is attributable to the belief that innovation is not a discrete event, but a result of the relationship quality existing between diverse actors (Puto et al., 2017). Several authors argue that customers have capabilities for creating and sharing idea that improve firms technical and economic innovation process. However, very few empirical studies were conducted to test, how social media activities dimensions are significantly related to product innovation in manufacturing firms. Therefore, based on Social Capital Theory, the primary purpose of this research is to examine the influence of social media platforms on innovation. Against this backdrop, the current research aims to methodically examine the 
variables that were used to influence innovation, and how social media activities can be empowering processes for product innovation. Additionally, this study aims to narrow the gap by examining the mediating role of relationship quality between the two dimensions social media activities and innovation, respectively.

\section{Literature Review}

\section{Innovation}

As indicated by Thompson (1965) innovation is the generation, acknowledgment, and usage of innovative thoughts, and products unique to the firm and intended to benefit it and its partners. Likewise, West and Anderson (1996) comparatively characterize "innovation as the viable use of procedures and novel products to the organization and intended to advantage it and its partners" cited by Wong Tjosvold, and Liu (2009, p. 238). Then again, Kimberly (1981) characterizes innovation from a substitute perspective which handles different kinds of innovation. According to Kimberly (1981) innovation can be categorized into three forms. For example, innovation is a procedure; a discrete thing like products, plans or services; and innovation is the quality of firms. Therefore, in the present dynamic environment, innovation has been found to be one of the best inspirations in both public and private organizations to produce sustainable competitive advantage (Subramaniam \& Youndt, 2005). According to Baregheh et al. (2009) innovation is now an inescapable factor for companies, which helps to improve and preserve a competitive advantage. Since 1990, the nature of innovation and the way it is observed have experienced significant changes. The source of innovation success has gone beyond a linear process of being productive in Research and Development (R\&D), enlightening significant management practices, and bringing new high-quality products, service, technology, and procedures to the market. According to Gertler and Wolfe (2002) innovation through learning today is not exclusively dependent on the discovery of scientific knowledge or formal R\&D activities but an interactive process with many feedback loops. Chesbrough (2006) discover that single firms are unable to effectively innovate in isolation. The learning processes nowadays evolve through interaction with a wide range of other organizations, to acquire ideas and resources, like suppliers, customers, competitors, universities, venture capitalists and government agencies in more or less open networks. The new concept of innovation is open thinking which is known as open innovation. The idea of open innovation creates companies to rethink their innovation management process. Based on open innovation theory, knowledge is no longer exploited just only from inside the company but also from outside of the companies' borders, as it is expected that this kind of purposive, inflows and outflows of the knowledge, technology, and resources will consequence in better innovation performance (van de Vrande et al., 2009). Open innovation thrives on the idea that external parties such as customers or users are sources of knowledge for firms (Walsh et al., 2016; Wang et al., 2015).

\section{Social Capital Theory}

Several scholars have conceptualized social capital as a strategic resource when companies establish associations with customers. Firms with good links with customers report better innovation activities through social relationships (Atuahene-Gima and Murray, 2007). Anderson et al. (2010, p. 121) defined social capital as a "networking platform of relationship where individuals capture resources which are generated by others or social units so that they can improve organizational effectiveness". Bagley and Hillyard (2014) defined social capital as the relationship between organizations and external institutions, which aids innovation, amongst others and reduce innovation costs tremendously (Lowitt et al., 2014; Eklinder-Frick et al., 2011). 
Social capital exists on different dimensions, and that installed relationship between the central organization and their crucial partners who assume an essential role in the company's innovation is especially significant (Yli-Renko \& Janakiraman, 2008). Different researchers, however, have embraced a more extensive meaning of social capital, in terms of the standards and qualities of the social relationship (Portes \& Sensenbrenner, 1993). Thus, social capital incorporates numerous parts of a social setting, for example, social ties, trust in relations, and esteem frameworks that encourage activities of people situated inside that unique circumstance. Nahapiet and Ghoshal (2000) proposed three elements of social capital: structural (the general example of associations between actors), cognitive (those resources providing shared portrayals, understandings, and frameworks of significance), and relational (the sort of personal connections individuals have created with one another through a background marked by cooperation). The cognitive element of social capital alludes to the resources that give parties a common language, shared vision, interpretations, and systems of importance. In sum, Nahapiet and Ghoshal (2000) proposed that the relational dimension alludes to the individual, relational dimension refers to individual relationships created through a past filled with collaborations, i.e., the degree to which trust, and a standard correspondence exist between the parties.

Consistent with a relational perspective on favourable competitive position (Hitt et al., 2000), this study used the structural dimension and cognitive dimension as user interaction activities where individuals or groups of participants can share ideas, and knowledge for product innovation processes or develop new products. These activities have been identified as broadcast search and ideation community contest (Piller et al., 2011; Terwiesch \& Xu, 2008). The relationship quality variable was developed from the relational dimension (Kühne et al., 2013; Chen et al., 2014). This examination helps fill the limitation in the literature by introducing these dimensions as customer interaction activities for sharing ideas, and knowledge for innovation activities (Piller et al., 2011), and how these dimensions in manufacturing firms are associated with its key customers that enables new knowledge for product innovation. This study contends that the measure of customer knowledge manufacturing firms will acquire from key customers relies upon social media activities. The dimension of social media activities is broadcast search, and ideation community contest. This study also expects that the quality of the relationship in terms of goodwill, trust, and reciprocity will accelerate innovation process by developing strong customer and firm's relationship (Lin \& Chen, 2018).

\section{Social Media}

The development of social media has empowered firms with various business models and immense marketing strategies which can be used to improve interest forecasts, allowing new administration practices, learning and upgrading development, sharing of information, cooperation and communication (Aral et al., 2013; Bughin \& Chui, 2013; Urquhart \& Vaast, 2012), while developing new approaches and tools to connect with many aspects of the innovation system (Jha \& Bose, 2016). Social media has indeed changed the traditional way of communication, collaboration and interaction with external environment (Carlson et al., 2018; Benitez et al., 2018) and its interactions with the innovation process (Papa et al., 2018; Lin et al., 2017).

Additionally, social media can positively affect firms' networking competencies and customer relationship management (Ghezzi et al., 2016). With these benefits, social media offers firms the possibility of collaborating with consumers, thereby enhancing consumer loyalty (Brodie 
et al., 2013; Mount \& Martinez, 2014). Through the social media platform, organizations are able to co-create value and collaborate with their users in product and co-development of products (Cheng \& Krumwiede, 2018; Pohjola \& Puusa, 2016). Using the process of active fan participation in diverse activities, new products can be developed, or existing products can be upgraded (Perlberg, 2015; Williams, 2017). Despite the usefulness of social media, there is a slightly different approach when using social media for core business and management purposes, such as innovation. This approach requires a useful platform. Many firms tend to perceive social media as an additional resource for product innovation, but they do not know how to measure its performance (Atanassova \& Clark, 2015). In this regard, firms can utilize the interactive social media environment to obtain customers' feedback and insights, which can be a critical source for future innovations, as in product development (Rathore et al., 2016). Through the feedback, firms can then utilize social media as a strategic tool to improve firm performance, revenues, and their competitive edge (Aral \& Weill, 2013; Oh et al., 2017).

Kim and Ko (2012) classified social media activities into: entertainment, interaction, trendiness, customization, and word-of-mouth by connecting them to extravagant brands (e.g. Gucci, Burberry, Chanel, Louis Vuitton, Yves Saint Laurent, Tealive, etc.). Seo and Park (2018) has added the perceived risk to these five (5) social media marketing activities in the airline business. Bilgin (2018) has defined social media activities as entertainment, interaction, trendiness, advertisement and customization. However, Lee (2017) explained that the social media activities of companies can be classified into communication, giving information, support for everyday life, advancement and selling, and social reaction and action. Lee (2017) was investigating the significance of companies' social media activities which compared consumers and companies. In another study, Parveen et al. (2015) when examining organization performance, found that, social media can be categorised as advertising and promotion, branding, information search, building customer relations. Piller et al. (2011) identified social media activities as the lead user involvement, toolkits usage, broadcast search, and ideation community contest, when examining social media on the co-creation of innovation. They found a significant positive impact of social media activities on innovation. Keinz et al. (2012) used three activities for the innovation process - lead user involvement, crowdsourcing, and toolkits usage. They found a significant effect of these activities on innovation. Panagiotopoulos et al. (2017) use crowd capabilities to examine the value of social media data in evidence-base policy. In this research, social media activities have been considered as Broadcast Search, and Ideation Community Contest.

\section{Broadcast Search and Innovation}

Broadcast search is an idea generation or problem-solving process for innovation where organization broadcast defined problems or product they want to develop to potential solvers and invite participants who seem to be qualified to provide ideas in the form of an open call for solutions (Jeppesen \& Lakhani, 2010; Corvello, 2013). Where other authors use the term crowdsourcing to describe the search for solution opportunities related to actual development tasks in the form of innovation (Afuah \& Tucci, 2012; Lüttgens et al., 2014). Crowdsourcing is a method to provide a new source of productivity, innovation, and co-creation (Woodcock et al., 2017). However, Gegenhuber and Hrelja (2012) in their study on broadcast search in innovation contests stated that broadcast search is the leading way to generate excellent ideas. According to Mahr et al. (2010) idea generation and problem-solving using broadcast search processes are most different from traditional problem-solving methods as different types of solvers involved in this process. In their study, they found that the broadcast search process is suitable for an organization when they do not have more time to solve the problem. According to Lakhani (2006) the broadcast search is an economically efficient problem-solving mechanism as it is a low-cost solution seekers method compare to internal R\&D cost. Several 
authors have found that broadcast search for idea generation form external source is positively related to product innovation (Terjesen \& Patel, 2017; Trantopoulos, 2017). According to Corvello (2013) broadcast search for innovation accelerates innovation processes because it exploits the knowledge and talent of a considerable number of individuals working outside the boundaries of an organization (Chesbrough, 2006). In this way organization predefined their innovation challenges to external actors (Jeppesen \& Lakhani, 2010).

Based on the literature discussed above we identified the solver come in the solving process at the marginal position. Marginal solvers can give perspectives to solve the specific solution or development and if may novel and useful for generating solutions for these problems or develop a new product. Though this process may not always be successful as marginal solvers have limited access to relevant problem information, lack of resources, and isolation. However, Gegenhuber and Hrelja (2012) stated that the context of broadcast search is a potential advantage of marginality. They found that technical and social marginality are statistically related to problem-solving success in a broadcast search setting. Therefore, the further study still needs to empirically analysis to understand how broadcast search processes supported by social media activities for innovation process in the interaction of social relationship between customers and organizations. Therefore, this study examines the effect of broadcast search on innovation in the Malaysian manufacturing industry. Base on the above literature review, the following hypotheses are developed:

\section{Hypothesis 1: Broadcast Search is a significant and positive impact on innovation.} Hypothesis 2: Broadcast Search is a significant and positive impact on relationship quality.

\section{Ideation Community Contest and Innovation}

Ideation community contest is being used to impact the early stage of the innovation process (Boudreau et al., 2011). In such a contest, organizations influence online communities to partake with thoughts regarding product improvement challenges, typically compensating the best submissions with financial rewards (Girotra et al., 2010). In this innovation, concept members are not only independently proposing ideas, but they also further develop ideas from other members (Ihl et al., 2012). Ideation community contest depicts a collective and dynamic conduct inside social innovation systems empowering and reaping the inventiveness of every one of its individuals to imagine crisp thoughts for the structure and advancement of new products, procedures, and administrations, or the improvement of existing ones. Basically, dependent on shared excitement and information concerning explicit product spaces and are frequently a virtual gathering place for imaginative users to examine openings and thoughts for new products and their improvement (Kozinets, 1999). According to Johann et al. (2004) ideation communities contest is a potential method for the innovation process, provided individuals are proficient and willing to add to virtual co-advancement. Piller et al. (2005) found that consumer joint efforts in innovation networks enable promising chances to produce an increasingly critical number of profitable thoughts through the fuse of customers' contemplations (thoughts) more rapidly and effectively than utilizing the conventional R\&D approaches. In addition, firms that follow this methodology can exhibit a more effective administration of changing customers' needs by including them into the esteem creation process. Autio et al. (2013) found that users attract attention from their peers in the community by coming up with novel and innovative ideas and engaging in technical problem-solving. They observe a positive relationship between ideation community contest and new opportunities. Community members can discover new issues and related solutions and communicate these within the community. Franke and Shah (2003) investigated four independent sports networks and demonstrated that $33 \%$ of the community individuals improved or even planned their 
product innovations for games gear. These innovations are not developed exclusively from individual endeavors but by joint efforts with other community individuals (Franke \& Shah 2003).

Keinz et al. (2012) expressed that ideation community contest are casual, self-composed (online) systems of users that share data and information about the product of the central maker firm. Rather than contending, users organized within an ideation community contest every now and again communicate and work together around a product of shared interest. As opposed to progressive systems or different types of systems, sharing forms between individuals in ideation community contest are not founded on formal contracts but rather on "relational contracts" in the feeling of trust, shared standards and qualities, and general correspondence (Murray \& O'Mahony, 2007). Backing to particular user pioneers from their friend community has been appeared to be an imperative achievement factor (Hienerth et al., 2011; Jeppesen \& Frederiksen, 2006) as it takes into account aggregate innovation, that is, expanding on the arrangements of others (Murray \& O'Mahony, 2007). Ideation community contest facilitate creative exercises in the ideation stage as well as in later phases of the innovation process (Raymond, 1999). Base on the above literature review, the following hypotheses are developed:

Hypothesis 3: Ideation Community Contest has a significant and positive impact on innovation. Hypothesis 4: Ideation Community Contest has a significant and positive impact on relationship quality.

\section{Relationship Quality and Innovation}

Relationship quality spotlights on the level of suitability of a relationship to satisfy the necessities of the consumer associated with the relationship. Subsequently, relationship quality catches the positive/negative nature of a relationship, which thus gives positive advantages to the customer. For instance, relationship quality has been appeared to improve operational execution and developing new products (Fernandes \& Pinto, 2019; Obal \& KannanNarasimhan, 2016). Wagner and Sutter (2012) demonstrated that excellent customer relationships improve supplier-customer joint innovation execution. Relationship Quality is the quality of the relationship that depicts the degree to which the desires of parties engaged in the relationship are met (Sven, 2004; Fernandes \& Pinto, 2019). Some literatures reveal that relationship quality is dependent on fulfilment and trust (Kühne et al., 2013; Chen et al., 2014). Thus, trust is an important element of relationship quality. Trusting relationships are vital in business associations, both between a business and its providers and between an organization and its customers. At the point when trust is built up among firms and their providers, firms are eager to request that providers collaborate during the time spent managing the innovation. Besides, firms with satisfied customers can effectively manage innovations on the off chance that they have superb relationships with such customers (Lin, \& Chen, 2018).

Torkildsen (2012) noticed that quality relationships satisfy customers. To establish a superb relationship, organizations are urged by partners and customers to live up to their needs and desires organizations that can effectively address these issues get by rivalry. Relationship quality is the psychological component of social capital which reflects basic qualities, social network, and relationship competitive advantage (Kang \& Na, 2018). Past investigations accentuated that increments in quality of relationship with community individuals contribute more than some other illustrative variable to improve organizations' innovation (Landry et al., 2002). Chiu et al. (2012) expressed that a trusted relationship leads to sharing and trading great quality learning for new improvement of the product. In aggregate, the quality of the relationship between an organization and its key customers ought to influence product 
innovation since it gives control, increases common comprehension, enlivens trade forms, and energizes opportunity in return. The quality of a relationship between an organization and its vital customer is reflected in the degree to which the two parties create common objectives, standards, and proportional assumptions about the exchange (Nahapiet \& Ghoshal, 2000). In the investigation of service quality and customer dedication Giovanis et al. (2015) found that relationship quality completely intercedes the service quality and customer loyalty relationship, while Keating et al. (2011) found that relationship quality partially mediates the relationship between service quality and customer loyalty interaction. In fact, several investigations have loaned support to this statement (Francisco-Maffezzolli et al., 2014; Fernandes \& Pinto, 2019). Kim and Cha (2002) found that relationship quality influences the customer-employee relationship where a higher relationship quality between the employee and customer significantly influences service innovation. Base on the above literature review, the following hypotheses are developed:

Hypothesis 5: Relationship Quality has a significant and positive impact on innovation.

Hypothesis 6: Relationship Quality has the mediating role in the relationship between Broadcast Search and Innovation.

Hypothesis 7: Relationship Quality has the mediating role in the relationship between Ideation Community Contest and Innovation.

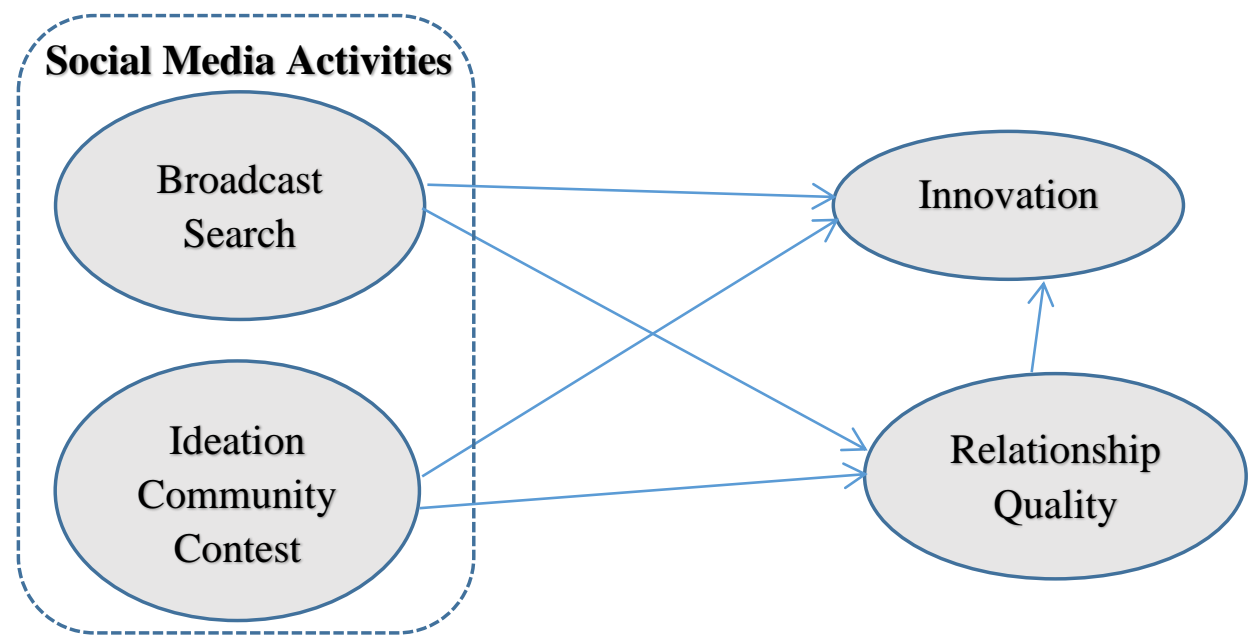

Figure 1: The Research Framework

\section{Methodology}

\section{Sampling Method and Unit of Analysis Technic}

We conducted a survey on 393 manufacturing firms located in Klang Valley, Malaysia. We focused on manufacturing firms, a significant economic contributor in Malaysia, because they have been thought to be most affected by key external relationships (van de Vrande et al., 2009). The population of this study comprised of employees (at least assistant managers, management team and/or owners) who are directly involved in the product operations and product development processes. The high-technology industry is chosen because it is appropriate for many reasons - it is knowledge-driven (Hatzichronoglou, 1997); its R\&D expenditures, patents and new products play a role in innovative performance (OECD, 1997); and rapid changes in market and technological developments in this industry make knowledge acquisition in exchange relationship particularly salient (Shan et al., 1994). To confirm that the sample firms are involved in technology creation, we checked their business profile from the 
Federation of Malaysian Manufactures (FMM) directory. A total 2,400 manufacturers, exporters and service companies' comprehensive profiles are listed in this directory. The manufacturing firms short-listed, through random, were contacted by telephone and after an initial inquiry, appointments were made for questionnaire distribution; and explanation was provided wherever needed. Each respondent represented one manufacturing firm. Therefore, we managed to a good response rate.

A pilot study has been conducted on 55 firms. The pilot data were entered into SPSS® v. 22 and analysed for reliability of measurements. The result of Cronbach's alpha for all the variables is above the .70 threshold, thus confirming reliability of the measurements used in this study. As indicated by Nunnaly and Berstein (1994) Cronbach's alpha of more than 0.7 is sensibly solid. Therefore, the same measurements scales were used on the actual collected data. In total, 536 questionnaires were distributed by online and personally; 405 respondents were returned from various industries. A total of 393 usable responses, from 393 firms, were considered "clean" and used for data analysis. The response rate is $68.23 \%$.

\section{Measurement of Variables and Data Analysis Techniques}

The concepts and measurement of broadcast search were developed based on the study conducted by Lakhani et al. (2007) and Lakhani (2006); for ideation community contest constructs were adopted from the study conducted by Laroche et al. (2012). Innovation was measured by using a five-items measurement scale, which was developed by Grawe et al. (2009). The measurement items for Relationship Quality constructs were adopted from wellestablished instruments in the previous study conducted by Chu et al. (2016) and Singh (2008). The final measurement items in Appendix I. All these scales were in a five-point Likert scale $(1=$ strongly disagree; $5=$ strongly agree, where a rating of $3=$ neutral). Respondents were approached to demonstrate their extent of agreement with proclamations regarding the broadcast search, ideation community contest, relationship quality and innovation process at their organization. The data collected for his study were analysed quantitatively. IBM SPSS $®$ Statistics v.22 and Analysis of Moment Structures (AMOS) v.22 were used to run the relevant statistical tests. Finally, the bootstrapping procedure in AMOS has been utilized to test mediating effect (Hayes, 2009). The next section provides the results attained from analysing the data via hypotheses testing.

\section{Results and Discussion}

\section{Demographic Profile of Respondents}

Out of 393 respondents majority of the respondents were female (255 or 64.9\%), in the age group of 31-40 years old (201 or 51.1\%), holding a Bachelor degree (268 or $68.20 \%$ ), were Senior Managers (182 or $46.30 \%$ ), and were working in the electronics \& electrical industry (132 or $33.6 \%)$.

\section{Confirmatory Factor Analysis (CFA)}

The initial model fit index for broadcast search, ideation community contest, innovation, and relationship quality showed that the model does not fit $(\mathrm{CMIN} / \mathrm{DF}=4.66$; $\mathrm{CFI}=.812$, which is lesser than .900; GFI $=.757$, which is lesser than .900 ; RMSEA $=.090$, which is more than .080). However, after removed week items found in initial CFA analysis, a re-specified measurement model, as shown in Table 1 shows the model fit index for user broadcast search, ideation community contest, innovation, and relationship quality. All 25 items indicated acceptable fit as the CMIN/DF value changed to 1.787 and significant (which is lesser than 
$5.0 ; p<.010)$. The CFI and GFI values improved respectively $(\mathrm{CFI}=.942$ and $\mathrm{GFI}=.909)$, while RMSEA reduced to .045 .

Table 1: Confirmatory Factor Analysis

\begin{tabular}{|c|c|c|c|c|c|c|c|}
\hline & & & Estimate & C.R. & $\mathrm{R}$ & $\mathrm{P}$ & Model Fit \\
\hline Broadcast Search & $\langle->$ & Ideation Contest & .095 & 6.173 & .424 & $* * *$ & \\
\hline Broadcast Search & $<->$ & Relationship & .058 & 5.098 & .376 & $* * *$ & CMIN/DG $=1.787$ \\
\hline Broadcast Search & $<->$ & Innovation & .053 & 4.626 & .315 & $* * *$ & $\begin{array}{l}\mathrm{P}=.000 \\
\mathrm{CEI}-\mathrm{0} 42\end{array}$ \\
\hline Ideation Contest & $<->$ & Relationship & .097 & 6.760 & .576 & $* * *$ & $\begin{array}{l}\mathrm{CFI}=.942 \\
\mathrm{GFI}=909\end{array}$ \\
\hline Ideation Contest & $<->$ & Innovation & .095 & 6.610 & .513 & $* * *$ & RMSEA $=.045$ \\
\hline Relationship & $<->$ & Innovation & .065 & 5.905 & .517 & $* * *$ & \\
\hline
\end{tabular}

\section{Reliability and Validity}

A reliability test was conducted to assess the items' internal degree of consistency and reliability in which case, Cronbach's alpha test was calculated for each of the items of broadcast search, ideation community contest, innovation, and relationship quality (Goforth, 2015). The reliability in Table 2 shows that the Cronbach's Alpha value of each variable is more than .700, demonstrating the reliability of the considerable number of scales as proposed by Hair et al. (2010).

We conducted convergent and discriminant validity tests of the constructs. As a result, shown in Table 2, Composite Reliability (CR) for all variables is greater than .700, and Average Variance Extraction (AVE) is higher than .500 which indicate the convergent validity of the variables (Hair et al., 2010).

Table 2: Reliability and Validity Analysis

\begin{tabular}{lcccc}
\hline Measurements & Number of Items & Cronbach's Alpha & CR & AVE \\
\hline Broadcast Search & 8 & .857 & 0.858 & 0.531 \\
Ideation Community Contest & 8 & .904 & 0.882 & 0.584 \\
Relationship Quality & 5 & .847 & 0.794 & 0.562 \\
Innovation & 4 & .833 & 0.834 & 0.503 \\
\hline
\end{tabular}

\section{Hypotheses Testing Using Structural Equation Modelling (SEM)}

SEM is a multivariate statistical technique which was used to analyse structural relationships between the measured variables and latent constructs (Statistics-Solutions, 2017). The research model in Figure 2, is a composite model that was developed based on the hypothesis of this study. In this model broadcast search, and ideation community contest are the predictor variables and innovation the dependent variable while relationship quality is the mediating variable. The result of the model fit summary in Figure 2 shows the significant value of CMIN/DF of $1.787(p=.000<.05)$; while the remaining values supported a model that fitted well $(\mathrm{CFI}=.942$; GFI $=.909$; RMSEA $=.045)$. Hence, we can conclude that the model fits. Furthermore, Table 3 shows that broadcast search is nonsignificant impact on innovation $(\mathrm{r}=$ $.068, p=0.262>0.050)$, but significantly and positively related to relationship quality $(\mathrm{r}=$ $.160, p=0.011<0.050)$. On the other interactions, ideation community contest significantly and positively related to innovation and relationship quality $(\mathrm{r}=.301, p=0.000<0.050)$ and $(\mathrm{r}=.508, p=0.000<0.050)$, respectively. Table 3 also indicated that relationship quality is significantly and positively related to innovation $(\mathrm{r}=.318, p=0.000<0.050)$. The results show 
that four hypotheses $(\mathrm{H} 1, \mathrm{H} 3, \mathrm{H} 4$, \& $\mathrm{H} 5)$ are supported and one hypothesis $(\mathrm{H} 2)$ is not supported.

Table 3: Hypothesis Testing

\begin{tabular}{|c|c|c|c|c|c|c|c|}
\hline & & & Estimate & S.E. & C.R. & $\mathrm{R}$ & $\mathrm{P}$ \\
\hline Relationship Quality & $<--$ & Ideation Contest & .401 & .061 & 6.570 & .508 & .000 \\
\hline Relationship Quality & $<---$ & Broadcast Search & .120 & .047 & 2.554 & .160 & .011 \\
\hline Innovation & $<---$ & Relationship Quality & .350 & .089 & 3.919 & .318 & .000 \\
\hline Innovation & $<---$ & Ideation Contest & .261 & .066 & 3.955 & .301 & .000 \\
\hline Innovation & $<---$ & Broadcast Search & .056 & .050 & 1.122 & .068 & .262 \\
\hline
\end{tabular}

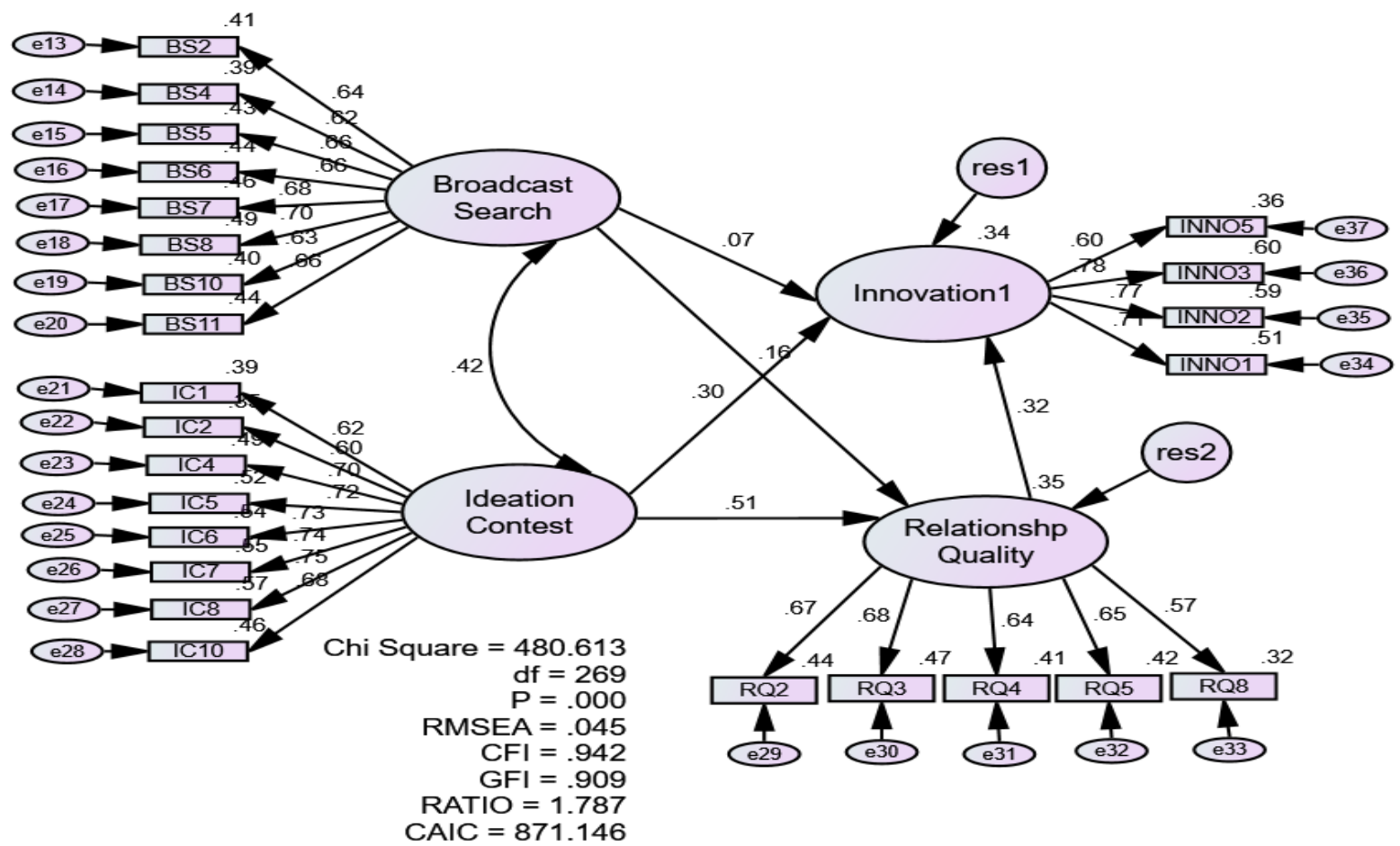

Figure 2: Structural Equation Modelling (SEM)

\section{Mediating Effect}

Table 4 displays the output of indirect effect of broadcast search and ideation community contest on innovation. As can be seen, the standardised coefficient for total effect (c) before entering the mediator (relationship quality) was not significant $(\mathrm{r}=.068 ; p=.262>0.05)$ for broadcast search, but it was significant for ideation community contest with $(\mathrm{r}=.301 ; p=.000$ $<0.05)$. This means that the broadcast search does not influence innovation, but ideation community contest fully influence innovation. Furthermore, the result in Table 4 shows that when relationship quality acts as a mediator, the influence of broadcast search on innovation remains non-significant but increase to reach $(\mathrm{r}=.244 ; p=.385>0.05)$. On the other side, when relationship quality acts as a mediator, the influence of ideation community contest on innovation remains significant, but beta/ $\mathrm{r}$ value reduces to $(\mathrm{r}=.258 ; p=.000<0.05)$.

Finally, on the indirect effects of broadcast search and ideation community contest, the bootstrapping procedure in AMOS was used and performed with, 5,000 resamples. Statistical significance for the indirect effect was determined from 99 percent bias and accelerated confidence intervals (Hayes, 2009). In this path it indicates that relationship quality does not Copyright (C) GLOBAL ACADEMIC EXCELLENCE (M) SDN BHD - All rights reserved 
transmit $(\mathrm{r}=.018 ; p=.108>0.05)$ of the influence of broadcast search on innovation with 99 percent confidence. We can conclude that the indirect effect of relationship quality is not significantly different from zero at $(p=.108>.05)$. However, in this path it indicates that relationship quality does transmit $(\mathrm{r}=.094 ; p=.000<0.05)$ of the influence of ideation community contest on innovation with 99 percent confidence. We can conclude that the mediating effect of relationship quality is significantly different from zero at $(p=.000<.05)$. As predicted, the results lend no support to a mediation model since the total effect of broadcast search on innovation is not significant when controlling relationship quality, but the results lend support to a partial mediation model since the total effect of ideation community contest on innovation is attenuated slightly but remained significant when controlling the relationship quality. Therefore, hypothesis 6 is not supported and hypothesis 7 is supported.

Table 4: Testing Indirect Effects (Mediation Variables)

\begin{tabular}{|c|c|c|c|c|c|}
\hline & Paths & $\begin{array}{l}\text { Direct without } \\
\text { Mediator }(\mathrm{P})\end{array}$ & $\begin{array}{l}\text { Direct with } \\
\text { Mediator }(\mathrm{P})\end{array}$ & $\begin{array}{c}\text { Indirect }(\mathrm{BC}) \\
\mathrm{P}\end{array}$ & Findings \\
\hline Broadcast & $\rightarrow$ Innovation & $.068(.262)$ & $.244(.385)$ & $.018(.108)$ & \\
\hline Ideation & $\rightarrow$ Innovation & $.301(.000)$ & $.258(.000)$ & $.094(.000)$ & Partial M \\
\hline
\end{tabular}

P: Probability, M: Mediation, BC: Bootstrap Confidence (Two Tailed Significance)

\section{Discussion and Conclusion}

This study aimed to understand and analyse the effect of broadcast search and ideation community contest on innovation and relationship quality. This research then analysed the effect of relationship quality on innovation. The main purpose of this study was to investigate the mediating role of relationship quality on the relationship among the independent variables and dependent variable. The findings of this study provided evidence showing the nonsignificant impact of broadcast search on innovation. As a result, it can be inferred that when the manufacturing organizations used the broadcast search for innovation, it did not lead to greater facilitation of innovation. This finding was different from previous findings where the role of broadcast search had played an important role in the innovation process (Jeppesen \& Lakhani, 2010). However, broadcast search in the marginal social context, some insignificant effects had also been reported such as limited access to relevant problem-information, lack of idea or resources, and isolation (Jeppesen \& Lakhani, 2010; Lakhani, 2006). The findings of this study had disclosed that Broadcast Search is not significantly associated with Innovation. This theoretical and empirical evidence derived from the current study implies that when Malaysian manufacturing firms use Broadcast Search activity for innovation process by collaborating with the customers, they seldom get an innovative idea. But broadcast search has found significant positive impact on relationship quality. As a result, it can be inferred that when organizations used broadcast search activity for customer interaction, it does lead to the greater facilitation of relationship quality (Frey et al., 2011).

However, the significant positive relationship of ideation community contest to innovation and relationship quality, respectively is supported by previous researches (Kärkkäinen et al., 2010; Piller et al., 2011; Groeger et al., 2016). The result indicated that when needed, organizations can use ideation community contest methods to engage customers in the innovation process (Aryobsei et al., 2012). Ideation community contest enable manufacturers to increase their innovation capability as well as reduce the uncertainty of customers' response to nextgeneration products (Piller et al., 2010). The findings from this study suggests that ideation community contest can be considered a valuable source of external opportunities for innovation (Zejnilovic et al., 2012). In the various manufacturing organizations, it is becoming increasingly popular to access customers' ideas for new product development (Bayus, 2013; 
Ihl et al., 2012). Similarly, Piller and Walcher (2006) stated that ideation community contest is a potential platform for idea generation and new product development. Autio et al. (2013), found that users attract attention form their peers in the community by coming up with novel and innovative ideas and engaging in technical problem-solving. As a result, it can be inferred that when organizations use an ideation community contest activity for relationship building, it increases relationship quality. The findings of this investigation support the argument of Bullinger et al. (2010). In their research, they found that ideation community contest is a technical solution activity where an individual wants to generate novel concepts and ideas for the organization without expecting money for their contribution (Ebner et al., 2009). Similarly, Bjork et al. (2011) stated that ideation community contest is a type of competitive mechanism of a relationship strategy for fostering the customer innovation process. The findings indicated that by using an ideation community contest activity, an organization could build a stronger relationship with the customer (Antikainen et al., 2010). Therefore, the findings of this investigation demonstrate that there is a significant and positive association among ideation community contest and relationship quality.

In our study we hypothesized that relationship quality is positively related with product innovation. The findings of this investigation support the argument of Wagner and Sutter (2012) who demonstrated that high-quality customer connections develop supplier-customer joint innovation execution. A previous study's result described that maximizing the trust of corporate relationships tends to increase green service innovation (Landry et al., 2002). This result was also supported by previous researches that highlighted the importance of relationship quality for product innovation, particularly with key customers (Lin \& Chen, 2018). Thus, relationship quality is the strength of customer relationship which significantly affects product innovation. Through high relationship quality, customers tend to take additional responsibilities to participate in the product innovation process. In a nutshell, the results of this research provide evidence on the significant effect of relationship quality on innovation. Our findings suggest a partial mediating effect of relationship quality on the relationship of ideation community contest and innovation (Giovanis et al., 2015; Chu et al., 2016; Lin \& Chen, 2018). This finding is also supported by previous investigation by Lin and Chen (2018). The reason for this could be that there are other factors that have a bigger impact on product innovation (Hamidi \& Gharneh, 2017; Chen et al., 2017).

\section{Implication for Theory and Practice}

There are practical and theoretical contributions from this study. First, this study reinforces the customer contribution in the firm's innovation process through the empirical investigation of broadcast search and ideation community contest. Both broadcast search and ideation community contest dimensions have significant effects on relationship quality and ideation community contest has significant impact on innovation as well. Second, the results confirm important implications for practitioners wanting to reap benefits from innovative products through ideation community contest. Third, this study brings to the fore the types of values garnered from broadcast search and ideation community contest. Moreover, this study empirically confirms the high-value ideation community contest can garner within the Malaysian context. Furthermore, this study's findings add to the literature of broadcast search and ideation community contest, innovation, and relationship quality within an emerging market setting. The fact that innovation is no longer a closed activity permeates the findings of this study. Embracing openness is one of the implicit implications of this study's findings, which is in line with the empirical outcome of another Malaysian study (Singh et al., 2016).

This study highlights how a manufacturing firm can achieve appropriate value from their key customers and show the way for competitive advantage. However, this study creates awareness 
about the importance of actively managing social capital to stimulate knowledge and build competitive advantage. These findings assist the operation manager by giving knowledge about their product innovation, firms growth and the potential in external knowledge.

\section{Limitation and Future Research}

Although this research provides numerous contributions, it still has some limitations. First, this investigation was limited to a particular area, and just the manufacturing organization in Malaysia was examined. Accordingly, the discoveries of this investigation may not be totally applicable and generalizable to other industries in the service sector. The manufacturing sector of high technology industries might be different from other low-technology manufacturing industries or service industries. Therefore, further study is necessary to verify and generalize these findings. Second, the data was collected from the firms only located in the Klang Valley area. Therefore, future studies could be conducted in other industries and other area settings.

\section{References}

Afuah, A., \& Tucci, C. L. (2012). Crowdsourcing as a solution to distant search. Academy of Management Review, 37(3), 355-375.

Anderson, A. R., Dodd, S. D., \& Jack, S. (2010). Network practices and entrepreneurial growth. Scandinavian Journal of Management, 26(2), 121-133.

Antikainen, M., Mäkipää, M. and Ahonen, M. (2010); "Motivating and Supporting Collaboration in Open Innovation", European Journal of Innovation Management, Vol. 13, No.1, pp. 100-119.

Aral, S., \& Weill, P. (2013). IT assets, organizational capabilities, and firm performance: How resource allocations and organizational differences explain performance variation. Organization Science, 18(5), 763-780.

Aral, S., Dellarocas, C., \& Godes, D. (2013). Introduction to the special issue-social media and business transformation: a framework for research. Information Systems Research, 24(1), 3-13.

Aryobsei, S., Hofstetter, R., \& Herrmann, A. (2012). On the Impact of Prior Ideas on Ideation Performance in Ideation Contests. ACR North American Advances.

Atanassova, I., \& Clark, L. (2015). Social media practices in SME marketing activities: A theoretical framework and research agenda. Journal of Customer Behaviour, 14(2), 163-183.

Atuahene-Gima, K., \& Murray, J. Y. (2007). Exploratory and exploitative learning in new product development: A social capital perspective on new technology ventures in China. Journal of International Marketing, 15(2), 1-29.

Autio, E., Dahlander, L., \& Frederiksen, L. (2013). Information exposure, opportunity evaluation, and entrepreneurial action: An investigation of an online user community. Academy of Management Journal, 56(5), 1348-1371.

Bagley, C., \& Hillyard, S. (2014). Rural schools, social capital and the Big Society: a theoretical and empirical exposition. British Educational Research Journal, 40(1), 6378.

Baregheh, A., Rowley, J., \& Sambrook, S. (2009). Towards a multidisciplinary definition of innovation. Management Decision, 47(8), 1323-1339.

Bayus, B. L. (2013). Crowdsourcing new product ideas over time: An analysis of the Dell IdeaStorm community. Management Science, 59(1), 226-244.

Benitez, J., Castillo, A., Llorens, J., \& Braojos, J. (2018). IT-enabled knowledge ambidexterity and innovation performance in small US firms: The moderator role of social media capability. Information \& Management, 55(1), 131-143. 
Bilgin, Y. (2018). The effect of social media marketing activities on brand awareness, brand image and brand loyalty. Business \& Management Studies: An International Journal, 6(1), 128-148.

Björk, J., Di Vincenzo, J. F., Magnusson, M. \& Mascia, D. (2011). The Impact of Social Capital on Ideation, Industry and Innovation, 18(6), 631-647.

Boudreau, K. J., Lacetera, N., \& Lakhani, K. R. (2011). Incentives and problem uncertainty in innovation contests: An empirical analysis. Management Science, 57(5), 843-863.

Brodie, R. J., Ilic, A., Juric, B., \& Hollebeek, L. (2013). Consumer engagement in a virtual brand community: An exploratory analysis. Journal of Business Research, 66(1), 105114.

Bughin, J., \& Chui, M. (2013). Evolution of the networked enterprise: McKinsey Global Survey results. McKinsey Quarterly, 29, 34-41.

Bullinger, A. C., Neyer, A. K., Rass, M., \& Moeslein, K. M. (2010). Community based innovation contests: Where competition meets cooperation. Creativity and Innovation Management, 19(3), 290-303.

Carlson, J., Rahman, M., Voola, R., \& De Vries, N. (2018). Customer engagement behaviours in social media: capturing innovation opportunities. Journal of Services Marketing, 32(1), 83-94.

Casidy, R., \& Nyadzayo, M. (2019). Drivers and outcomes of relationship quality with professional service firms: An SME owner-manager perspective. Industrial Marketing Management, 78, 27-42.

Chen, J. S., Kerr, D., Chou, C. Y., \& Ang, C. (2017). Business co-creation for service innovation in the hospitality and tourism industry. International Journal of Contemporary Hospitality Management, 29(6), 1522-1540.

Chen, S. C., Jong, D., \& Lai, M. T. (2014). Assessing the relationship between technology readiness and continuance intention in an E-appointment system: relationship quality as a mediator. Journal of Medical Systems, 38(9), 1-12.

Cheng, C. C., \& Krumwiede, D. (2018). Enhancing the performance of supplier involvement in new product development: the enabling roles of social media and firm capabilities. Supply Chain Management, 23(3), 171-187.

Chesbrough, H. W. (2006). Open innovation: The new imperative for creating and profiting from technology. Harvard Business Press.

Chiu, C. C., Wang, J. J., Tsai, T. C., Chu, C. C., \& Shi, H. Y. (2012). The relationship between volume and outcome after bariatric surgery: a nationwide study in Taiwan. Obesity surgery, 22(7), 1008-1015.

Chu, Z., Wang, Q., \& Lado, A. A. (2016). Customer orientation, relationship quality, and performance: The third-party logistics provider's perspective. The International Journal of Logistics Management, 27(3), 738-754.

Corvello, V. (2013). An empirical study of individual factors affecting the usefulness of internet-based platforms for open innovation in broadcast search processes. International Journal of Digital Content Technology and its Applications, 7(4), 821.

Ebner, W., Leimeister, J. M., \& Krcmar, H. (2009). Community engineering for innovations: the ideas competition as a method to nurture a virtual community for innovations. $R \& d$ Management, 39(4), 342-356.

Edelman, L. F., Bresnen, M., Newell, S., Scarbrough, H., \& Swan, J. (2004). The benefits and pitfalls of social capital: Empirical evidence from two organizations in the United Kingdom. British Journal of Management, 15, 59-69. 
Fernandes, T., \& Pinto, T. (2019). Relationship quality determinants and outcomes in retail banking services: The role of customer experience. Journal of Retailing and Consumer Services, 50, 30-41.

Eklinder-Frick, J., Eriksson, L. T., \& Hallén, L. (2011). Bridging and bonding forms of social capital in a regional strategic network. Industrial Marketing Management, 40(6), 9941003.

Francisco-Maffezzolli, E. C., Semprebon, E., \& Prado, P. H. M. (2014). Construing loyalty through brand experience: The mediating role of brand relationship quality. Journal of Brand Management, 21(5), 446-458.

Franke, N., \& Shah, S. (2003). How communities support innovative activities: an exploration of assistance and sharing among end-users. Research Policy, 32(1), 157-178.

Frey, K., Lüthje, C., \& Haag, S. (2011). Whom should firms attract to open innovation platforms? The role of knowledge diversity and motivation. Long Range Planning, 44(5-6), 397-420.

Gegenhuber, T., \& Hrelja, M. (2012). Broadcast search in innovation contests: case for hybrid models. arXiv preprint arXiv: 1204.3343.

Gertler, M., \& Wolfe, D. (Eds.). (2002). Innovation and social learning: institutional adaptation in an era of technological change. Springer.

Ghezzi, A., Gastaldi, L., Lettieri, E., Martini, A., \& Corso, M. (2016). A role for startups in unleashing the disruptive power of social media. International Journal of Information Management, 36(6), 1152-1159.

Giovanis, A., Athanasopoulou, P., \& Tsoukatos, E. (2015). The role of service fairness in the service quality-relationship quality-customer loyalty chain: An empirical study. Journal of Service Theory and Practice, 25(6), 744-776.

Girotra, K., Terwiesch, C., \& Ulrich, K. T. (2010). Idea generation and the quality of the best idea. Management Science, 56(4), 591-605.

Goforth, C. (2015). Using and Interpreting Cronbach's Alpha. Retrieved from http://data.library.virginia.edu/using-and-interpreting-cronbachs-alpha/

Grawe, S. J., Chen, H., \& Daugherty, P. J. (2009). The relationship between strategic orientation, service innovation, and performance. International Journal of Physical Distribution \& Logistics Management, 39(4), 282-300.

Groeger, L., Moroko, L., \& Hollebeek, L. D. (2016). Capturing value from non-paying consumers' engagement behaviours: field evidence and development of a theoretical model. Journal of Strategic Marketing, 24(3-4), 190-209.

Hair, J. F., Black, W. C., Babin, B. J., \& Anderson, R. E. (2010). Multivariate Data Analysis: Prentice Hall.

Hamidi, F., \& Gharneh, N. S. (2017). Impact of co-creation on innovation capability and firm performance: a structural equation modeling. AD-minister, 30(1), 73-90.

Hatzichronoglou, T. (1997). Revision of the high-technology sector and product classification. OECD Science, Technology an Industry Working Papers: OECD Publishing.

Hayes, A.F. (2009). Beyond Baron and Kenny: statistical mediation analysis in the new millennium. Communication Monographs, 76(4), 408-420.

Hienerth, C., Keinz, P., \& Lettl, C. (2011). Exploring the nature and implementation process of user-centric business models. Long Range Planning, 44(5-6), 344-374.

Hitt, M. A., Dacin, M. T., Levitas, E., Arregle, J. L., \& Borza, A. (2000). Partner selection in emerging and developed market contexts: Resource-based and organizational learning perspectives. Academy of Management Journal, 43(3), 449-467.

Ihl, C., Vossen, A., \& Piller, F. T. (2012). All for the money? The ambiguity of monetary rewards in firm-initiated ideation with users. Innovation Management 19(4), 385-396. 
Jeppesen, L. B., \& Frederiksen, L. (2006). Why do users contribute to firm-hosted user communities? The case of computer-controlled music instruments. Organization Science, 17(1), 45-63.

Jeppesen, L. B., \& Lakhani, K. R. (2010). Marginality and problem-solving effectiveness in broadcast search. Organization Science, 21(5), 1016-1033.

Jha, A. K., \& Bose, I. (2016). Innovation research in information systems: A commentary on contemporary trends and issues. Information \& Management, 53(3), 297-306.

Johann, F., Bartl, M., Ernst, H., \& Hans, M. (2004). Community based innovation-a method to utilize the innovative potential of online communities. In null (p. 70195c). IEEE.

Jussila, J. J., Kärkkäinen, H., \& Leino, M. (2013). Innovation-related benefits of social media in Business-to-Business customer relationships. International Journal of Advanced Media and Communication, 5(1), 4-18.

Kang, S., \& Na, Y. K. (2018). The effect of the relationship characteristics and social capital of the sharing economy business on the social network, relationship competitive advantage, and continuance commitment. Sustainability, 10(7), 2203.

Kaplan, A. M. \& Haenlein, M. (2010). Users of the world, unite! The challenges and opportunities of Social Media. Business Horizons, 53(1), 59-68.

Kärkkäinen, H., Jussila, J., \& Väisänen, J. (2010). Social media use and potential in businessto-business companies' innovation. In Proceedings of the 14th international academic mindtrek conference: Envisioning future media environments (228-236). ACM.

Keating, B. W., Alpert, F., Kriz, A., \& Quazi, A. (2011). Mediating role of relationship quality in online services. Journal of Computer Information Systems, 52(2), 33-41.

Keinz, P., Hienerth, C., \& Lettl, C. (2012). Designing the organization for user innovation, Journal of Organization Design, 1(3), 20-36.

Kim, A. J., \& Ko, E. (2012). Do social media marketing activities enhance customer equity? An empirical study of luxury fashion brand. Journal of Business research, 65(10), 1480-1486.

Kim, W. G., \& Cha, Y. (2002). Antecedents and consequences of relationship quality in hotel industry. International Journal of Hospitality Management, 21(4), 321-338.

Kimberly, J. R. (1981). Managerial Innovation In NYSTROM, PC, STARBUCK, WH (ed) Handbook of Organizational Design. Adapting Organisations to Their Environments.

Kozinets, R. V. (1999). E-tribalized marketing? The strategic implications of virtual communities of consumption. European Management Journal, 17(3), 252-264.

Kühne, B., Gellynck, X., \& Weaver, R. D. (2013). The influence of relationship quality on the innovation capacity in traditional food chains. Supply Chain Management: An International Journal, 18(1), 52-65.

Lakhani, K. R. (2006). Broadcast Search in Problem Solving: Attracting Solutions from the Periphery1. In Technology Management for the Global Future, 2006. PICMET 2006 (6), 2450-2468). IEEE.

Lakhani, K. R., Jeppesen, L. B., Lohse, P. A., \& Panetta, J. A. (2007). The value of openess in scientific problem solving (07-50). Boston, MA: Division of Research, Harvard Business School.

Landry, R., Amara, N., \& Lamari, M. (2002). Does social capital determine innovation? To what extent? Technological forecasting and social change, 69(7), 681-701.

Laroche, M., Habibi, M. R., Richard, M. O., \& Sankaranarayanan, R. (2012). The effects of social media-based brand communities on brand community markers, value creation practices, brand trust and brand loyalty. Computers in Human Behavior, 28(5), 17551767. 
Laursen, K., \& Salter, A. (2006). Open for innovation: the role of openness in explaining innovation performance among UK manufacturing firms. Strategic Management Journal, 27(2), 131-150.

Lee, S. (2017). A study on different recognition of importance in enterprises' social media activities based on comparison between consumers and enterprise: Focusing on commercial and relational characteristics of activity types. Master's Dissertation). Hankuk University of Foreign Studies, South Korea.

Lichtenthaler, U., \& Ernst, H. (2008). Innovation intermediaries: Why internet marketplaces for technology have not yet met the expectations. Creativity and innovation management, 17(1), 14-25.

Lin, X., Li, Y., \& Wang, X. (2017). Social commerce research: Definition, research themes and the trends. International Journal of Information Management, 37(3), 190-201.

Lin, Y. H., \& Chen, H. C. (2018). Critical factors for enhancing green service innovation: Linking green relationship quality and green entrepreneurial orientation. Journal of Hospitality and Tourism Technology, 9(2), 188-203.

Lowitt, K., Hickey, G. M., Ganpat, W., \& Phillip, L. (2014). Developing communities of practice in support of resilient value chains for sustainable food security. World Development, 74, 363-373

Lüttgens, D., Pollok, P., Antons, D., \& Piller, F. (2014). Wisdom of the crowd and capabilities of a few: internal success factors of crowdsourcing for innovation. Journal of Business Economics, 84(3), 339-374.

Mahr, D., Rindfleisch, A., \& Slotegraaf, S. (2010). Innovation Beyond Firm Boundaries: The Routines of Successful External Problem Solvers. In Tilburg Conference for Innovation, Tilburg, The Netherlands.management system, Management, 21(2), 170184. http://ssrn.com/abstract=2083422

Mount, M., \& Martinez, M. G. (2014). Social media: A tool for open innovation. California Management Review, 56(4), 124-143. https://doi.org/10.1525/cmr.2014.56.4.124

Murray, F., \& O'Mahony, S. (2007). Exploring the foundations of cumulative innovation: Implications for organization science. Organization Science, 18(6), 1006-1021.

Nahapiet, J., \& Ghoshal, S. (2000). Social capital, intellectual capital, and the organizational advantage. In Knowledge and Social Capital (119-157): Elsevier.

Nunnally and Berstein (1994), Psychometric theory ( $3^{\text {rd }}$ ed.), New York: McGraw-Hill.

Obal, M., Kannan-Narasimhan, R., \& Ko, G. (2016). Whom should we talk to? Investigating the varying roles of internal and external relationship quality on radical and incremental innovation performance. Journal of Product Innovation Management, 33, 136-147.

OECD, (1997). Revision of High Technology Sector and Product Classification. Paris: OECD.

Oh, C., Roumani, Y., Nwankpa, J. K., \& Hu, H. F. (2017). Beyond likes and tweets: Consumer engagement behavior and movie box office in social media. Information \& Management, 54(1), 25-37.

Orcik, A., Tekic, Z., \& Anisic, Z. (2013). Customer co-creation throughout the product life cycle. International Journal of Industrial Engineering and Management, 4(1), 43-49.

Palacios-Marqués, D., Merigó, J. M., \& Soto-Acosta, P. (2015). Online social networks as an enabler of innovation in organizations. Management Decision. 53 (9), 1906-1920.

Panagiotopoulos, P., Bowen, F., \& Brooker, P. (2017). The value of social media data: Integrating crowd capabilities in evidence-based policy. Government Information Quarterly, 34(4), 601-612.

Papa, A., Santoro, G., Tirabeni, L., \& Monge, F. (2018). Social media as tool for facilitating knowledge creation and innovation in small and medium enterprises. Baltic Journal of Management, 13(3), 329-344. 
Parveen, F., Jaafar, N. I., \& Ainin, S. (2015). Social media usage and organizational performance: Reflections of Malaysian social media managers. Telematics and Informatics, 32(1), 67-78.

Perlberg, S. (2015). How Netflix is shaking up its marketing strategy. The Wall Street Journal. Retrieved from https://blogs.wsj. com/cmo/2015/04/16/netflix-marketing-strategy/

Piller, F. T., \& Walcher, D. (2006). Toolkits for idea competitions: a novel method to integrate users in new product development. $R \& d$ Management, 36(3), 307-318.

Piller, F., Schubert, P., Koch, M., \& Möslein, K. (2005). Overcoming mass confusion: Collaborative customer co-design in online communities. Journal of ComputerMediated Communication, 10(4), JCMC1042.

Piller, F., Vossen, A., \& Ihl, C. (2011). From social media to social product development: the impact of social media on co-creation of innovation. Die Unternehmung, 65(1), 1-22.

Piller, Frank T., Ihl, C., and Vossen, A., (2010). A Typology of Customer Co-Creation in the Innovation Process. Available at SSRN: http://dx.doi.org/10.2139/ssrn.1732127.

Pohjola, I., \& Puusa, A. (2016). Group dynamics and the role of ICT in the life cycle analysis of community of practice-based product development: a case study. Journal of Knowledge Management, 20(3), 465-483.

Portes, A., \& Sensenbrenner, J. (1993). Embeddedness and immigration: Notes on the social determinants of economic action. American Journal of Sociology, 98(6), 1320-1350.

Prahalad, C. K., \& Ramaswamy, V. (2004). Co-creation experiences: The next practice in value creation. Journal of Interactive Marketing, 18(3), 5-14.

Puto, U. I. Keut, R. I. Ni Nyoman K. Y. \& Putu S. I. (2017). The Mediating Role of Relationship Quality in Association of Brand Performance and Repurchase Intention: Evidences of Balinese Traditional Food Business at Star Hotels. International Journal of Business and Management Invention, 6(6), 2319-8028.

Ramaswamy, V. (2008). Co-creating value through customer's experiences: The Nike case. Strategy \& Leadership, 36(5), 9-14.

Rathore, A. K., Ilavarasan, P. V., \& Dwivedi, Y. K. (2016). Social media content and product co-creation: an emerging paradigm. Journal of Enterprise Information Management, 29(1), 7-18.

Raymond, E. (1999). The cathedral and the bazaar. Knowledge, Technology \& Policy, 12(3), 23-49.

Ritala, P., Hurmelinna-Laukkanen, P., (2013). Incremental and radical innovation in coopetition the role of absorptive capacity and appropriability. J. Prod. Innov. Manag. 30 (1), 154-169.

Scuotto, V., Del Giudice, M., Della Peruta, M. R., \& Tarba, S. (2017). The performance implications of leveraging internal innovation through social media networks: An empirical verification of the smart fashion industry. Technological Forecasting and Social Change, 120, 184-194.

Seo, E. J., \& Park, J. W. (2018). A study on the effects of social media marketing activities on brand equity and customer response in the airline industry. Journal of Air Transport Management, 66, 36-41.

Shan, W., Walker, G., \& Kogut, B. (1994). Interfirm cooperation and startup innovation in the biotechnology industry. Strategic Management Journal, 15(5), 387-394.

Singh, R. (2008). Relational embeddedness, tertius iungens orientation and relationship quality in emerging markets. Asia Pacific Journal of Marketing and Logistics, 20(4), 479-492.

Singh, S. K. G., Jayasingam, S. \& Klobas, J. (2016). Open innovation: Do inbound and outbound practices affect firm performance? The $30^{\text {th }}$ Australian and New Zealand Academy of Management Conference, ANZAM, Queensland University of Technology, 
Brisbane, Australia, 6-9 Dec 2016, 1-23. Retrieved from http://www.anzam.org/pastevent-material/past-conference-papers/.

Statistics-Solutions. (2017). Structural Equation Modelling. Retrieved from http://www.statisticssolutions.com/structural-equation-modeling/

Subramaniam, M., \& Youndt, M. A. (2005). The influence of intellectual capital on the types of innovative capabilities. Academy of Management Journal, 48(3), 450-463.

Sven Ivens, B. (2004). How relevant are different forms of relational behavior? An empirical test based on Macneil's exchange framework. Journal of Business \& Industrial Marketing, 19(5), 300-309.

Terjesen, S., \& Patel, P. C. (2017). In search of process innovations: The role of search depth, search breadth, and the industry environment. Journal of Management, 43(5), 14211446.

Terwiesch, C., \& Xu, Y. (2008). Innovation contests, open innovation, and multiagent problem solving. Management Science, 54(9), 1529-1543.

Thompson, V. A. (1965). Bureaucracy and innovation. Administrative science quarterly, 1-20.

Torkildsen, G. (2012). Torkildsen's sport and leisure management. Routledge ( $6^{\text {th }} \mathrm{ed}$.) London.

Trantopoulos, K., von Krogh, G., Wallin, M. W., \& Woerter, M. (2017). External knowledge and information technology: Implications for process innovation performance. MIS Quarterly, 41(1), 287-300.

Tripp, T. M., \& Grégoire, Y. (2011). When unhappy customers strike back on the Internet. MIT Sloan Management Review, 52(3), 37-44.

Urquhart, C., Vaast, E., 2012. Building social media theory from case studies: a new frontier for IS research. In: Proceedings of the 33rd International Conference on Information Systems (ICIS), Orlando.

Van de Vrande, V., De Jong, J. P., Vanhaverbeke, W., \& De Rochemont, M. (2009). Open innovation in SMEs: Trends, motives and management challenges. Technovation, 29(6-7), 423-437.

von Hippel, E. (2001). Toolkits Usage for innovation. Journal of Product Innovation Management: An international ublication of the product development \& management association, 18(4), 247-257.

Wagner, S. M., \& Sutter, R. (2012). A qualitative investigation of innovation between third-party logistics providers and customers. International Journal of Production Economics, 140(2), 944-958.

Walsh, J. P., Lee, Y. N., \& Nagaoka, S. (2016). Openness and innovation in the US: Collaboration form, idea generation and implementation. Research Policy, 45(8), 16601671.

Wang, C. H., Chang, C. H., \& Shen, G. C. (2015). The effect of inbound open innovation on firm performance: Evidence from high-tech industry. Technological Forecasting and Social Change, 99, 222-230.

West, M. A., \& Anderson, N. R. (1996). Innovation in top management teams. Journal of Applied Psychology, 81(6), 680.

Williams, D. (2017). 4 content marketing lessons to learn from Netflix. Retrieved from https://www.entrepreneur.com/article/294050

Wong, A., Tjosvold, D., \& Liu, C. (2009). Innovation by teams in Shanghai, China: cooperative goals for group confidence and persistence. British Journal of Management, 20(2), 238251.

Woodcock, J., Greenhill, A., Holmes, K., Graham, G., Cox, J., Oh, E. Y., \& Masters, K. (2017). Crowdsourcing citizen science: Exploring the tensions between paid professionals and users. Journal of Peer Production, 10. 
Zahra, S. A., \& Covin, J. G. (1994). The financial implications of fit between competitive strategy and innovation types and sources. The Journal of High Technology Management Research, 5(2), 183-211.

Zejnilovic, L., Oliveira, P., \& Veloso, F. M. (2012). Employees as user innovators: An empirical investigation of an idea management system. Available at SSRN 2083422.

\section{Appendix I}

\section{Broadcast Search:}

1 *Broadcast search helps firms to collect new development ideas.

2 Firms can have a better understanding of the clients' needs and expectations.

3 *Sharing idea and knowledge improves firms' innovation efficiency.

4 Broadcast search is a highly efficient way to perform technical problem-solving.

5 Firms can use external sources of knowledge and technology when developing new products

5 through broadcast searching.

Customers' feedback in the broadcast search leads to a chain of actions to produce the right products and/or services.

The broadcast is an economic exchange relation, both from firm to customer as well as from customer to customer relationship.

8 Customers can obtain favorable information about the firm's products from various sources via broadcast search.

9 *Broadcast search allows firms to gather information about customers' post-purchase behavior.

10 Customers' feedback via broadcast is a rich source of innovative idea.

11 Firms can create highly interactive platforms via broadcast search by updating product and/or services information daily.

*Firms can invite customers to exchange ideas regarding new product and/or service development

from time to time.

13 * Increase in customer satisfaction in general, or as a direct result of a new product and/or service.

*Through broadcast search, firms are able to achieve Real-time customization of products and/or services.

\section{Ideation Community Contest}

1 If the firm wants to make changes to its equipment, the firm needs to know enough people who could help the firm do so.

2 When the firm encounters technical problems, the firm knows exactly who to ask for advice.

3 *The firm knows many users who have a thorough knowledge of the product and equipment.

4 The firm can find people who possess all of the abilities that the firm would require to make 4 improvements to their product and equipment.

5 If the firm wants to make changes to its product and equipment, the firm could count on getting positive feedback about the changes from the fellow users.

6 The firm knows many users who are capable of repairing the equipment.

7 The firm has no difficulty in using the online community system.

8 The community contest helps to bring like-minded people together for product innovation.

9 *The community contest is useful for gathering various information about the products and/or services.

10 The community contest allows for direct user input or posting to the innovation process. *Customers exchange information about the firm and the firm's products and/or services with the community. 


\section{Relationship Quality:}

1 *Maintaining the relationship with this major user is our business' maximum effort.

2 The relationship with this major user is something our business really cares about.

3 The relationship with this major user is something our business intends to maintain indefinitely.

4 The relationship with this major user is very important to our business.

5 The relationship with this major user is something to which we are very committed.

6 *The major user is trustworthy.

7 *Our firm trusts that this major user keeps our best interests in mind.

8 This major user considers our welfare as well as its own when making important decisions.

\section{Innovation:}

1 New ideas are readily accepted in our firm's product and/or service development.

2 Our firm's top management gives special emphasis to product and/or service innovation.

3 Our firm constantly seeks new ways to better our product and/or service to our customers.

4

*Our firm is able to change/modify our current service approaches to meet customers' special requirements.

5 Compared to our competitors, our firm is able to come up with new product and service offerings.

*Week items has been removed from the final model test. 